\title{
Corpus Stylistic Analysis of Malaysian Online Columnists
}

\author{
Siti Aeisha Joharry \\ aeisha@uitm.edu.my \\ Akademi Pengajian Bahasa, UiTM Shah Alam \\ Syamimi Turiman \\ syamimituriman@uitm.edu.my \\ Akademi Pengajian Bahasa, UiTM Shah Alam
}

\begin{abstract}
Online media creates various platforms by which people can view and make sense of the world today. In this paper, two Malaysian columnists from two national English online portals: The Star Online and News Straits Times were selected for a corpus-assisted stylistics discourse analysis. Frequency lists were firstly compared between each columnist to identify salient words that are used by each writer. Initial observation shows that a number of words refer to law/policy [e.g. act, law(s)] and government/public (e.g. constitution, parliament). From the comparing wordlists feature, stylistic comparisons are further explored using Hyland's (2005) interactional metadiscourse features. The use of the first-person pronoun 'I' was also investigated, which McNair (2008) regards as typical of commentary journalism. Although findings show that both columnists employ similar metadiscoursal features, Syahredzan projects a more assertive stance (I have, know) as opposed to John Teo who is more suggestive in style (I think, believe). Results thus present columnists' style of writing, which are significant for readers when deciding on a piece of news and to be critically aware of how persuasiveness can be constructed in journalistic discourse.
\end{abstract}

Keywords: Corpus linguistics, media discourse, online newspapers, corpus-assisted discourse analysis, stylistics 


\section{Introduction}

Corpus linguistics is an area of study that is expanding and its present-day popularity is due to the interest in the techniques used, as it deals with "some set of machine-readable texts which is deemed an appropriate basis on which to study a specific set of research questions" (McEnery \& Hardy, 2012, p. 1). In other words, corpus linguistics involves the use of computers to search and analyse a collection of real language (Vaughan \& O'Keeffe, 2015). The number of language disciplines that utilize corpus linguistics has grown rapidly, which includes media discourse on various issues such as newsworthiness (Bednarek \& Caple, 2014), representation of Islam (Baker, Gabrielatos \& McEnery, 2013), migrants (Taylor, 2014), and feminism in media (Jarwoska \& Krishnamurthy, 2012).

At present, there are 5.11 billion mobile users, making online media the preferred platform to access news and features on current affairs, among others. Online media allows for new ways for readers to consume news and make sense of the world today. With the ability to simultaneously reach a mass and highly dispersed audience, online media has developed into a setter of agenda and moulder of public opinion (Djerf-Pierre \& Shehata, 2017). This explains the increase of journalistic commentary, and how events are reported through the lens of columnists.

News has been a common area for research (e.g. Bird, 2011; O’Keeffe, 2011), and language of newspapers is identified as one of the four major registers in the English language, along with spoken conversation, academic writing and fiction (Biber, Johansson, Leech \& Finegan, 1999). Since media discourse is public, it garners the attention of discourse analysts and increasingly so because of the online availability of newspapers (O'Keeffe, 2011). While it is easy to obtain news stories presented in the online newspapers, people reading the news pick and choose stories they want to attend to and believe, and select from a seemingly endless supply of information to assemble their own versions' (Bird, 2011: p. 504). This highlights the role of columnists in the information chain. Online columns have a significant role in reporting the news, presenting informed summaries and interpretations of events and issues from their point of view to reach the public. As McNair (2008) puts it, this type of journalism (also known as commentary journalism) revolves around "making sense" of events and therefore their roles are more than mere reporting, "but also a sifter and sorter of an accelerating, increasingly voluminous flow of information into news items of differential value ... [j] ournalism expanded its remit from the production of facts ... to the construction of meanings" (p. 106). 
However, in media discourse, the language used by columnists has yet to be examined further-most linguistic studies on media discourse have investigated news/weblogs (e.g. Reese et al., 2007; Baker et al., 2013; Bednarek \& Caple, 2014). Studies on columnists' writing in column pieces tend to be underpinned by media study background (McNair, 2008; Meikle, 2008) whereas linguistic analyses on opinion pieces are rather limited (except for a few: Fu \& Hyland, 2014; Noorian \& Biria, 2010). According to Fu and Hyland (2014), contrary to typical news reporting, opinion pieces take a more personal interactional position, adopting a clear perspective towards both their topics and their readers by establishing a stance early on in the piece and supporting this with a range of warrants for their opinions. What is key to opinion texts is the writer's explicitly subjective attitude and open judgments of the issues (Fu \& Hyland, 2014, p. 4), which are therefore interesting to be studied. To the best of the authors' knowledge, a study has yet to explore how Malaysian columnists construct their material and present this to readers, drawing on the resources of interactional metadiscourse.

This leads to the present study for understanding the ways writers manage interaction by intruding and commenting on their message -how they express solidarity, anticipate objections and respond to an imagined dialogue with others (Fu \& Hyland, 2014, p. 6). In today's globalised world, news is now easily obtained via the click of the mouse, particularly with the advent of the internet. This brings about important value for investigating how interactions about news within a text differ when they are transmitted via the online medium, and how they shape media discourse of a particular society. As Hall (2008, p. 222) notes, “[j] ournalism's dual role in the information age is to act as an informed moderator for that interaction and the cartographer of the information that feeds it". Moreover, the integration of both discourse analysis and corpus linguistics techniques has "identified conventionalised discursive devices that are repeatedly used in news discourse to construct and perpetuate an ideology of newsworthiness" (Bednarek \& Caple, 2014, p. 40) that in turn, would render a piece of news reporting to be more persuasive and garner wider readability.

So far, most research findings have resulted from non-linguistic studies of Western media. This is argued to be not "equally applicable" (Bernstein \& Galily, 2008, p. 181) to other countries where dominant discourses that might be found in Asian media, such as Malaysia, might differ from those of Western media due to distinct socio-cultural values and practices. As a result, the current study is necessary to be carried out in Malaysia. This study thus aims to investigate 
differences in writing style, particularly of two online columnists from two mainstream Malaysian local online news portals, guided by the following research questions:

1. What are the stylistic differences between two local journalistic commentary writing?

2. How does a corpus-assisted stylistic approach to media discourse able to highlight salient patterns of writers' rhetoric/writing strategies (metadiscoursal features)?

\section{Literature Review}

The literature on corpus work in media discourse is extensive as more studies have investigated language use in media via empirical methods like those offered in corpus linguistics (e.g. Bednarek \& Caple, 2014; Marchi, 2018). As a form of delineation, this section is divided into two: describing past relevant studies in two corpus approaches -CADS or corpus-assisted discourse analysis, and corpus-assisted stylistics.

\subsection{CADS and Media Discourse}

Apart from the traditional Conversation Analysis (CA), media discourse is also generally examined using approaches such as Discourse Analysis (DA) and Critical Discourse Analysis (CDA) (Fairclough, 1995; Wodak, 2001; \& van Djik, 1993). These approaches are mainly qualitative in nature, and are based on close readings of texts (Jarwoska, 2016). Both DA and CDA are effective methods in the identification of norms and ideologies in media discourse through the interplay between context, text and language in smaller sets of media data. However, the findings obtained from the analysis are difficult to generalise beyond the studied cases. Due to this reason, analysts interested in media discourses are increasingly adopting the tools and methods of Corpus Linguistics (CL), which provides the study to be more empirical (O'Halloran, 2010).

An alternative to these traditional qualitative analyses is Corpus-assisted Discourse Studies (CADS), which offers a convenient method through corpus investigation, combining close reading with statistical analysis in the investigation of media discourse. CADS approach allows for quantitative results produced by corpus tools to be studied in more depth using the qualitative discourse-analytic studies. The combination of the quantitative corpus techniques with more qualitative methods has been identified as effective methodological synergies (Partington, 2006; 
Baker et al., 2008) to reveal language patterns and representations in the media when compared with a quantitative or qualitative analysis alone.

\subsection{Corpus-assisted Stylistics: A Practical Approach to Examine Rhetoric in Online} Columns/ Opinion Pieces

The research on investigating writing style or 'stylistics' have originally been literary, including those that incorporate corpus such as Culpeper's (2002) analysis of Shakepeare's characters in Romeo and Juliet and Mahlberg's (2013) work on Dickens, to name a few. However, more corpus studies have examined stylistic features such as irony, metaphor and word-play to be found in nonliterary discourse such as those in newspaper writing (e.g. Semino \& Short, 2004; Bednarek, 2006).

Two similar characteristics of corpus stylistic studies and CADS are that both approaches are usually (if not, mostly) contrastive and that methods/techniques are a combination of various linguistic analyses and definitely employ use of computational software like WordSmith Tools, AntConc, WMatrix and others. More importantly, Partington et al. (2013) assert that the incorporation of statistical corpus methods to studies in stylistics are essential as to highlight “particular distinctive tendencies within an author's - or groups of authors' - style which may warrant further scrutiny" (p.168). A number of studies examine metadiscoursal features as a rhetorical distinction of opinion pieces as a genre like Fu and Hyland (2014), and Mengyu and Hajar (2019). Noorian and Biria (2010) more specifically, compared opinion pieces written by American and Iranian columnists and discovered that the choice of metadiscourse markers are also culturally driven.

Hyland (2005) asserts that metadiscoursal features are facilitating tools on social communication, which in turn reveal the ways that writers project themselves into their argumentation in order to control their interactive intentions and signal their perspectives and commitments (p.14). Hyland's (2005) interpersonal model of metadiscourse includes an array of features which assist writers to relate a text to its context, and enables writers to control the level of personality in a text to establish a suitable relationship with their audience. The model recognizes that metadiscourse is comprised of the two dimensions of interaction, as can be seen in Table 1 below: 
Table 1: Interpersonal model of metadiscourse (Hyland, 2005, p49)

\begin{tabular}{|c|c|c|}
\hline Category & Function & Examples \\
\hline Interactive & $\begin{array}{l}\text { Help to guide the reader } \\
\text { through the text }\end{array}$ & \\
\hline Transitions & $\begin{array}{l}\text { express relations between } \\
\text { main clauses }\end{array}$ & $\begin{array}{l}\text { in addition; but; } \\
\text { thus; and }\end{array}$ \\
\hline $\begin{array}{l}\text { Frame } \\
\text { markers }\end{array}$ & $\begin{array}{l}\text { refer to discourse acts, } \\
\text { sequences or stages }\end{array}$ & $\begin{array}{l}\text { finally; to conclude; } \\
\text { my purpose is }\end{array}$ \\
\hline $\begin{array}{l}\text { Endophoric } \\
\text { markers }\end{array}$ & $\begin{array}{l}\text { refer to information in other } \\
\text { parts of the text }\end{array}$ & $\begin{array}{l}\text { noted above; see } \\
\text { Fig.; in section } 2\end{array}$ \\
\hline Evidentials & $\begin{array}{l}\text { refer to information from } \\
\text { other texts }\end{array}$ & $\begin{array}{l}\text { according to } X ; Z \\
\text { states }\end{array}$ \\
\hline Code glosses & $\begin{array}{l}\text { elaborate propositional } \\
\text { meanings }\end{array}$ & $\begin{array}{l}\text { namely; e.g.; such } \\
\text { as; in other words }\end{array}$ \\
\hline Interactional & $\begin{array}{l}\text { Involve the reader in the } \\
\text { text }\end{array}$ & \\
\hline Hedges & $\begin{array}{l}\text { withhold commitment and } \\
\text { open dialogue }\end{array}$ & $\begin{array}{l}\text { might; perhaps; } \\
\text { possible; about }\end{array}$ \\
\hline Boosters & $\begin{array}{l}\text { emphasize certainty or close } \\
\text { dialogue }\end{array}$ & $\begin{array}{l}\text { in fact; definitely; it } \\
\text { is clear that }\end{array}$ \\
\hline $\begin{array}{l}\text { Attitude } \\
\text { markers }\end{array}$ & $\begin{array}{l}\text { express writer's attitude to } \\
\text { proposition }\end{array}$ & $\begin{array}{l}\text { unfortunately; I } \\
\text { agree; surprisingly }\end{array}$ \\
\hline $\begin{array}{l}\text { Self- } \\
\text { mentions }\end{array}$ & $\begin{array}{l}\text { explicit reference to } \\
\text { author(s) }\end{array}$ & I; we; my; me; our \\
\hline $\begin{array}{l}\text { Engagement } \\
\text { markers }\end{array}$ & $\begin{array}{l}\text { explicitly build relationship } \\
\text { with readers }\end{array}$ & $\begin{array}{l}\text { consider; note; you } \\
\text { can see that }\end{array}$ \\
\hline
\end{tabular}

These features provide a means for understanding the ways in which writers manage interaction and explicate how different kinds of texts demonstrate the interactive process of a discourse. Corpus-assisted stylistic studies examining metadiscourse features in online opinion pieces thus in 
turn, are interesting to reveal how writers demonstrate rhetorical strategies in order to represent their understanding of reality as well as drawing on a sense of commonality with their readers.

The purpose of this paper is to then explore stylistic differences between two local journalistic commentary writing and how combining corpus and stylistic approaches to media discourse is feasible in eliciting salient metadiscoursal features amongst columnists. In so doing, we examined the language used in two Malaysian English language online columns. More specifically, corpus techniques are employed to elicit differences among the two columnists' writing style. We firstly describe the corpus and methodology below, then go on to analyse the texts in the subsequent section.

\section{Methodology}

This study is underpinned by the corpus linguistics methodology (see Tognini-Bonelli, 2001) and in turn, the first step is to compile the corpus. This corpus consists of articles retrieved from the columnist section of two widely readable mainstream Malaysian online newspapers: The Star Online and News Straits Times. It is important to note here that these online news portals are referred to as the online edition of their typical broadsheets. As Rogers (2019) rightfully points out, "[t]he online versions of these broadsheets, however, are more tabloid-like in format; they have flashier headlines, attention-grabbing colour, and more graphics than the print editions".

Therefore, the caveat here is to not treat the online portals as their original broadsheet equivalents since it is undeniable that this form of journalism 'seems to be to capture readers' attention with tabloid techniques instead of relying on a more in-depth, broadsheet-like, serious tone" (Rogers, 2019), and therefore, would be more interesting to study.

In order to select columnists that would be appropriate for this study, a quick search was done by clicking on the 'Columnists' tab of the respective online news portals to find writers with the most articles. This eventually came down to Syahredzan Johan ${ }^{1}$ (a total of 132 articles at the time of collection) for The Star Online and John Teo (259 articles) for the NST. The articles were collected from the year the columnists began their writing career, which was the year 2013 for John Teo and 2014 for Syahredzan Johan until September 2019. Although both writers did not necessarily began writing for their columns during the same time, it could be argued that both had

\footnotetext{
${ }^{1}$ It was later discovered that Syahredzan Johan is no longer part of the columnist section in The Star Online, but his writings should still be applicable for study.
} 
almost similar years of experience for writing a column in a national newspaper agency and are therefore considered to be professional writers/columnists in their own right. Table 2 shows the two corpora in detail:

Table 2: Corpus description

\begin{tabular}{|l|l|l|}
\hline Columnist & Syahredzan & John Teo \\
\hline Words & 90,721 & 194,815 \\
\hline Texts & 132 & 259 \\
\hline Source & The Star Online & $\begin{array}{l}\text { News Straits Times } \\
\text { (NST) }\end{array}$ \\
\hline
\end{tabular}

Using WordSmith Tools 6.0 (Scott, 2012), the two corpora are firstly compared to each other by using the 'compare two wordlists' feature. This corpus technique basically helps make stylistic comparisons. In other words, by comparing the separate wordlists, we are able to identify similar/different words used between the two writers in their columns. The procedure compares all the words in both lists and will report on all those which appear significantly more often in one than the other, including those which appear more than the minimum number of times in one even if they do not appear at all in the other (Scott, 2012). In this study, we restricted the words to those occurring with a minimum of 10 times in at least 5 texts using log-likelihood. By doing this, keywords of one columnist means that these words are statistically more significant than its occurrence in the other column.

Following this, shared keywords in both corpora will be analysed further since salient words that are used by both columnists would be more interesting for comparing purposes. Collocational analysis, i.e. investigation of co-occurring words surrounding selected keywords is then conducted by specifying associations within a span of 5 words to the right and left of a word, occurring at least 1 time, and with an MI-score value of more than 3. As mentioned in Hunston (2002), MI measures the strength of association between a word and its collocate. Having identified salient keywords and their collocates, further qualitative analysis is then carried out by investigating metadiscoursal features following Hyland (2004; 2005), and examination of the first person pronoun 'I' (McNair, 2008). 


\section{Findings and Discussion}

In order to examine stylistic differences between the two columnists, the two wordlists are firstly compared using the 'compare two wordlists' function in WordSmith Tools 6.0. Table 3 presents top 50 key words that appear significantly more often in Syahredzan than in John Teo's. Initial observation shows that a number of words relates to law/policy (e.g. act, law(s), court) and government/public (e.g. constitution, parliament), which would describe the topics that are more commonly written by Syahredzan compared to John Teo. Some words are not found in John Teo's columns (e.g. seditious, offences, liberties, and mentri), and while other topic-related words such as 'act, law/laws, court, and constitution' were found, they appeared only few compared to being more frequent in Syahredzan's writings. This is probably because Syahredzan is a lawyer by profession and his writings are more suggestive of the law/political genre. These initial findings from Table 3 reveal a clear distinction of what topics may be found in one corpus relative to another - in this case, genre plays a significant role in projecting content words that are more topic-related to the discipline and thus, would be used to describe Syahredzan's style of writing as more political over John's.

Interestingly, some words that are not topic-related are found to be significantly more frequent in Syahrezdan compared to John Teo's, namely personal pronouns (you, we, your, I), modal verbs (would, must, should), deictic marker these, existential/action verbs (is, are, do), conjunctions (or, also), article the, and the negated form not. This means that Syahredzan uses these words more often than John Teo would and therefore, firstly suggests how different their writing could be. In contrast to content words that would indicate the aboutness of the texts mentioned earlier, functional words describe more of the writers' style (or rhetorical strategies) and in turn, are examined further in 4.1 using Hyland's (2005) metadiscoursal features. 
Table 3: Top 50 words that are significantly more frequent in Syahredzan compared to John Teo

\begin{tabular}{|c|c|c|c|c|}
\hline $\mathbf{N}$ & Key word & $\begin{array}{c}\text { freq. in Syahredzan } \\
\text { Johan_files }\end{array}$ & $\begin{array}{c}\text { freq. in John } \\
\text { Teo_files }\end{array}$ & Keyness \\
\hline 1 & act & 335 & 56 & 490.52 \\
\hline 2 & you & 238 & 25 & 400.07 \\
\hline 3 & law & 304 & 73 & 382.93 \\
\hline 4 & person & 194 & 15 & 348.68 \\
\hline 5 & court & 222 & 33 & 338.15 \\
\hline 6 & laws & 177 & 15 & 312.30 \\
\hline 7 & or & 739 & 606 & 308.20 \\
\hline 8 & information & 167 & 13 & 299.73 \\
\hline 9 & submission & 133 & 1 & 294.10 \\
\hline 10 & humble & 133 & 2 & 285.83 \\
\hline 11 & constitution & 184 & 27 & 281.39 \\
\hline 12 & syahredzan & 111 & 0 & 254.63 \\
\hline 13 & myt & 111 & 0 & 254.63 \\
\hline 14 & johan & 111 & 0 & 254.63 \\
\hline 15 & freedom & 161 & 22 & 251.74 \\
\hline 16 & the & 7036 & 11988 & 249.29 \\
\hline 17 & monday & 107 & 1 & 234.86 \\
\hline 18 & we & 631 & 564 & 226.40 \\
\hline 19 & offence & 105 & 2 & 222.51 \\
\hline 20 & $\mathrm{am}$ & 120 & 10 & 212.42 \\
\hline 21 & not & 983 & 1135 & 198.35 \\
\hline 22 & speech & 94 & 4 & 185.26 \\
\hline 23 & sedition & 88 & 2 & 184.20 \\
\hline 24 & article & 96 & 8 & 169.92 \\
\hline 25 & expression & 83 & 3 & 166.65 \\
\hline 26 & is & 1689 & 2430 & 157.47 \\
\hline 27 & parliament & 151 & 51 & 157.11 \\
\hline 28 & your & 89 & 8 & 155.02 \\
\hline 29 & are & 771 & 895 & 152.99 \\
\hline 30 & would & 282 & 204 & 141.75 \\
\hline 31 & police & 89 & 14 & 132.96 \\
\hline 32 & security & 98 & 21 & 129.94 \\
\hline 33 & section & 60 & 1 & 128.18 \\
\hline 34 & religion & 79 & 10 & 126.29 \\
\hline 35 & bill & 101 & 25 & 125.24 \\
\hline 36 & must & 348 & 312 & 123.91 \\
\hline 37 & people & 261 & 198 & 122.49 \\
\hline 38 & these & 267 & 206 & 122.18 \\
\hline 39 & according & 63 & 4 & 117.25 \\
\hline 40 & rights & 156 & 81 & 115.37 \\
\hline 41 & legal & 86 & 20 & 109.88 \\
\hline 42 & criminal & 62 & 6 & 106.20 \\
\hline 43 & right & 173 & 107 & 106.19 \\
\hline 44 & do & 240 & 191 & 104.67 \\
\hline 45 & muslims & 87 & 23 & 104.33 \\
\hline
\end{tabular}




$\begin{array}{lcccc}46 & \text { dewan } & 56 & 4 & 102.11 \\ 47 & \text { seditious } & 44 & 0 & 100.91 \\ 48 & \text { media } & 140 & 75 & 100.38 \\ 49 & \text { offences } & 42 & 0 & 96.33 \\ 50 & \text { liberties } & 41 & 0 & 94.03\end{array}$

\subsection{Comparison of WordList Feature}

Given that the comparison feature includes all significant key words occurring at least once in a wordlist regardless of the other list, we specified only shared keywords between both corpora to be analysed further (see Appendix). The shared keywords were then further categorised based on Hyland's (2005) interpersonal model of metadiscourse, as seen in Table 4 below. This resulted in the words appearing in both Syahredzan and John's columns that are more comparable for analysis -highlighting that the values in brackets represent words occurring statistically more significant in Syahredzan than in John Teo's. It should be noted that the identification of metadiscoursal features based on individual lexical items, especially interactive ones, may be misleading without looking at the context further. Therefore, the list of examples below serves only as a description of possible metadiscourse found in both columnists' writing.

Table 4: Metadiscoursal features used by both columnists

\begin{tabular}{|l|l|}
\hline Category & Examples \\
\hline $\begin{array}{l}\text { Interactive } \\
\text { Transition }\end{array}$ & also $(91.27)$, however $(27.50)$ \\
$\begin{array}{l}\text { Frame markers } \\
\text { Endophoric }\end{array}$ & - \\
markers & who* $(60.62)$, found $*(29.67)$ \\
Evidentials & $(33.77)$ \\
Code glosses & - \\
\hline Interactional & \\
Hedges & should $(90.63)$, would $(141.75)$ \\
Boosters & - \\
Attitude markers & want $(32.17)$ \\
Engagement & we* $(226.40)$, you $(400.07)$, people $(122.49)$, \\
markers & muslims $(104.33)$, citizens $(35.78)$, society (58.15), \\
Self-mention & rakyat $(41.43)$, \\
\hline
\end{tabular}

\footnotetext{
* These examples may have two functions within the same category and therefore is listed twice
} 
As can be seen in Table 4, interactive features only include transitions (also, however), endophoric markers (who, found) and evidentials (say, claim). It is important to point out here that 'who' and 'found' may also function as evidentials where writers refer to external sources that help them build their stance, for instance He cites the example one of the rightly guided Caliphs, Umar alKhattab, who suspended the hudud crime of theft during a year of famine (Syahredzan) and The Court of Appeal found that Section 3(3) did not meet the test of proportionality (Syahredzan). Frame markers and code glosses are not found to be frequent in both columnists' writing and this may signal a lesser preference to do discoursal acts, sequences (finally; to conclude) or elaborate on propositional meanings (namely; e.g.) (Hyland, 2005). However, as mentioned earlier, further examination of the concordance lines is needed to discern how interactive metadiscourse is used in both writings.

In terms of interactional resources, Malaysian online columnists employed engagement markers the most, through the use of explicitly addressing readers - noticeably by lexical items such as pronouns we and you, and those signalling groups of people (people, muslims, citizens, society, and rakyat). The columnists attempt to create a sense of unity or solidarity through addressing the readers as 'people' (e.g. A Malaysian prime minister is accountable to his cabinet colleagues, to Parliament, to components of his ruling coalition, to states, to the rulers and ultimately, to the people come time for a general election - John Teo); 'muslims' (e.g. And Malays and Muslims are made to look irrational and extreme, not to mention illogical - Syahredzan; As Malaysian Muslims celebrate overcoming personal trials and tribulations over Ramadhan... John Teo); and 'citizens' (e.g. The State's business is not to ensure that citizens are not offended Syahredzan). Another common group reference is to the people of Malaysia often referred to as 'rakyat', for instance, Instead of relying on the Opposition parties to balance the Government, the rakyat can be at the frontline keeping the Government in check (Syahredzan). These examples of collective references reveal how columnists position themselves interactionally, where O'Keeffe (2006) describes as reflecting a collective identity.

However, concordance lines for 'rakyat' in John Teo's columns were not used for the same purpose in Syahredzan. Instead, John Teo made reference to political parties like Pakatan Rakyat, Parti Rakyat Sarawak, Parti Bersatu Rakyat Sabah and others, indicating a specific audience as presented in Figure 1: 


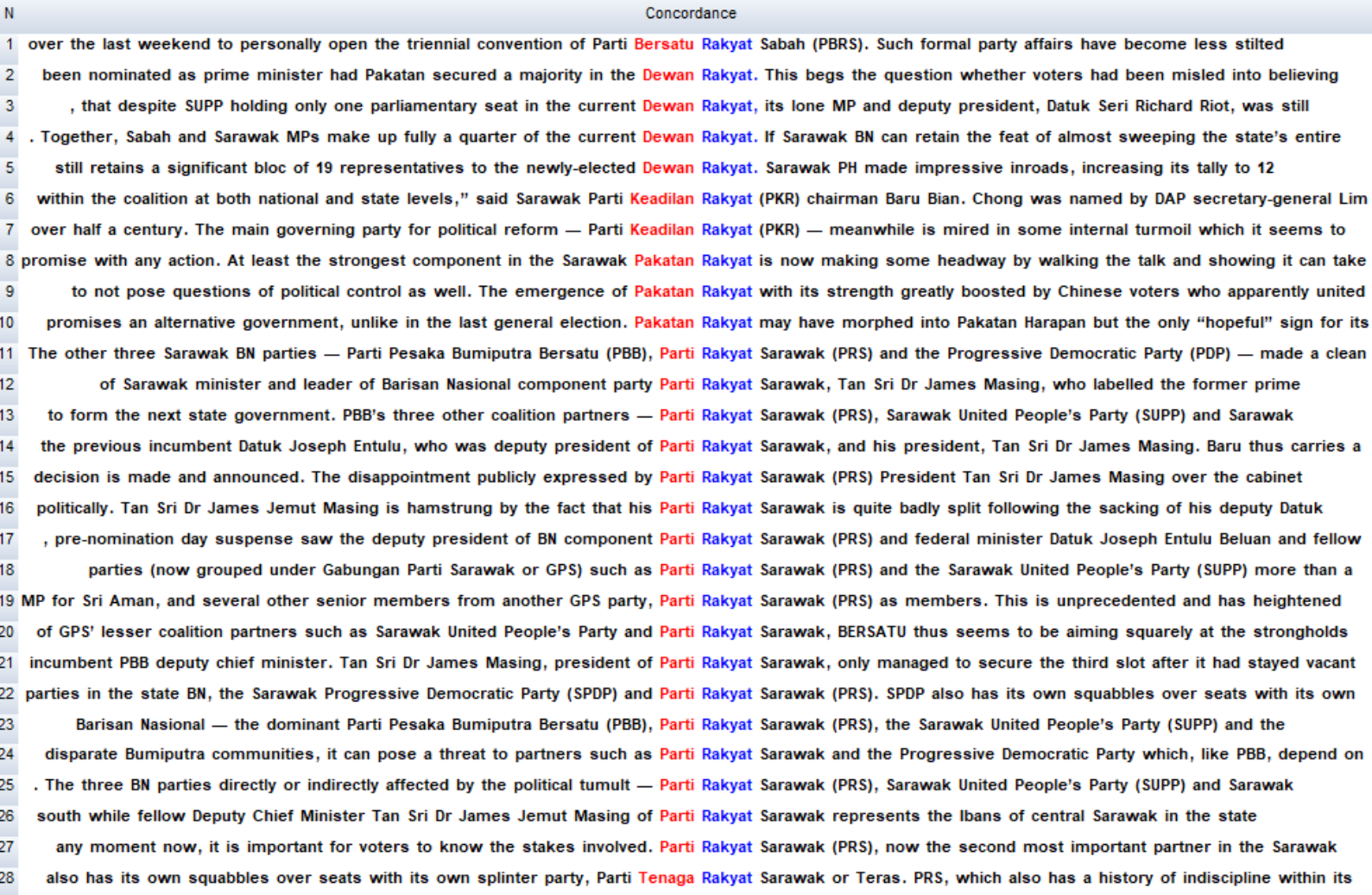

Figure 1: 'Rakyat' in John Teo

For the engagement marker 'we', the caveat here is to recognise the use of the personal plural pronoun as an inclusive we, which could be used in contexts that refer to shared knowledge or form of solidarity, and in turn may also act as self-mentions. Inclusive we as a self-mention, also reflects a solidarity marker in which O'Keeffe (2006: p137) states, functions as "to appropriate speaking authority on behalf of audience" and therefore inadvertently engages readers to the text. This can be seen in the examples below. The first person pronoun 'I' on the other hand, would be explained later in the next section along with discussion on the use of 'I' as a trait of the columnist following McNair (2008).

Examples of inclusive-we

1) For us in Malaysia, a far more effective use of any leverage and influence we may have over the course Myanmar takes will not be one of disapproving censure, but rather of pointing it in the right direction - perhaps by way of the power of our own example, for what it may be worth (John Teo) 
2) Taking offence is normal. It is a human reaction. We have different degrees of tolerance (Syahredzan)

Fu and Hyland (2014) noted that 'you' is a highly interactive feature which grabs the reader's attention and invites a direct involvement in the unfolding argument (p.10). Interestingly, Syahredzan was found to use 'you' significantly higher (400.07), suggesting that he makes more involvement of the readers in the process of communication, making them (i.e. readers) his 'partner' in the process (e.g. Meanwhile, Article 9 provides that citizens, like you, have the right to freedom of movement). On the contrary, John Teo makes less instances of 'you', and when he does so, they resemble expressions like be careful what you wish for, you bet we do, ...if you will. While this paper does not make comparisons with other personal deixes like 'they, them, their', it would be interesting to look at how columnists view themselves and their readers in what O'Keeffe (2006, p. 139) argues as the “"otherness' [that] is constructed through pronoun choice”.

The columnists also employed hedges frequently to 'withhold commitment to a claim' (Hyland, 2005, p. 52). In the data, it was found that both columnists used should and would relatively frequent, allowing for subjectivity of a proposition to be presented as an opinion rather than a fact. Examples include proposing something to be a certain way (e.g. This is how it should be -Syahredzan; There should be nothing to prevent Sarawak asserting all its political rights overnight if it chooses -John Teo), suggesting something as the opposite (e.g. A caretaker government should not, for example, do anything which may bind the new government Syahredzan; That said, the lesson of Umno's downfall should not be lost on PBB-John Teo); and asking a rhetorical question (e.g. Should you just write off the debt? -Syahredzan; Should it be making a stand publicly about probably the single biggest national scandal ever and which unseated an incumbent national government for the first time? -John Teo). These then describe the way in which columnists present their personal views and perspectives towards a certain issue, particularly by minimising their imposition about a claim. This concurs with the findings of Noorian and Biria (2014) who mentioned that hedging can be considered as 'an important characteristic of professional writing'. Thus, hedges appear to be an essential element in expressing persuasiveness in online opinion columns.

While there is little variety in the use of attitude markers in both columnists' opinion pieces, writers are found to employ 'want' to demonstrate a sense of volition as well as indicate their 
affective attitude towards certain propositions. Interestingly, samples of the use of want in both columnists' writings can be classified into a number of categories. The first one is to denote volition from the perspective of the writer (e.g. I am in danger of burning out so I need to pace myself as I want to be in this for the long run-Syahredzan). Volition is also expressed in terms of the inclusive 'we' (e.g. Malaysians want a more open and transparent and accountable government. We want to know what the government is doing -Syahredzan; but yet we somehow, almost inexplicably, always want to cling on to...- John Teo), as well as to position the volition to others (e.g. They do not want a cooperation with individuals which they do not like - Syahredzan; the new chief minister will have his own leadership style and will want to stamp his own imprint, - John Teo). Another type is where 'want' is used in a hypothetical 'if'-statement such as but if we truly want to empower the people, this is the way forward (Syahredzan).

Since opinion pieces mainly function to convey the columnists' stance on a topic and to recruit readers into agreeing to their stance, it is worth noting that the attitude marker 'want' appear in the corpora mostly to highlight what writers feel and how they feel about what others may think/feel. One of the differences in the writing styles of the two columnists is that Syahredzan demonstrates a wider use of volition by employing 'want' when expressing affective attitude towards propositions. For instance, he expresses his hope about his personal journey as a lawyer with his readers (example above), involving the reader via engagement marker 'you' (e.g. You are still free to say whatever you want, even about the person who blocked you) and promoting solidarity through use of the inclusive 'we' (example above), as well as presenting something in a hypothetical way via the 'if'-clause (e.g. What if he does not want to resign?).

$\mathrm{Fu}$ and Hyland (2014, p. 22) assert that 'such strong expressions of attitude insinuate a shared response to situations, implying agreement on understanding the world and bringing readers around to the author's uncontroversial conclusions', as seen in the following examples:

3) However, if you want to make institutional reforms or change the law, it must be through the legislative process, in which our elected representatives represent the larger populace $[. .$.$] To say that you do not want to choose a candidate because there are no real$ choices is an argument that does not hold water - Syahredzan 
Interestingly, John seems to express this sense of volition through instances of hedging, such as shown below:

4) Malaysians, like Americans, always conscious of how their respective carefully ordered societies may potentially be rent asunder by unforeseen events or careless individual remarks, however inconsequential they may appear if taken in isolation, may want to take to heart the socially redeeming lesson that Charleston offers us - John Teo

From these examples, it is observed that attitude markers did not only signal the columnists' attitude towards certain propositions, it can also be seen that Syahredzan performs these actions specifically through use of 'want' - more frequently and without "beating around the bush". Also, use of attitude markers like 'want' in the instances shown above create an informal tone and thus, making Syahredzan's writings more personal, “creating a bond with the readers and securing the readers' agreements with their [Syahredzan] arguments" (Fu \& Hyland, 2014, p22). The last metadiscoursal feature which is self-mention will be examined more closely in the ensuing subsection.

\subsection{The Use of ' $I$ '}

McNair (2008, p. 109) stresses that "[a]s opposed to the detached objectivity of the reporter or correspondent, the columnist stresses the "I'". As can be seen in Table A1 in Appendix, the use of 'I' is over-used in Syahredzan (18\%) as opposed to John Teo's (6\%). Collocational analyses of the use of ' $I$ ' with the immediate word to the right $(I+1 \mathrm{R})$ in both columns are then further examined. This means patterns would indicate how writers used the first person pronoun to show what they think/feel about something and most importantly, their opinions about a piece of news.

Table 5: Collocates for 'I' in both corpora

\begin{tabular}{|c|c|}
\hline Columnist & Collocates for 'I' \\
\hline Syahredzan & $\begin{array}{l}\text { myself }(8.71), \text { wrote }(7.96) \text {, am } \mathbf{( 5 . 6 8 )} \text {, feel }(5.67) \text {, love }(5.43), \text { know } \\
(5.25) \text {, did (4.47), also }(3.87) \text {, was } \mathbf{( 3 . 5 5 )} \text {, do (3.54), and have } \mathbf{3 . 3 6})\end{array}$ \\
\hline John Teo & $\begin{array}{l}\text { am (10.64), think (9.21), would (5.7), can (4.44), had (4.35), only } \\
(4.08) \text {, was (3.99), and have (3.3) }\end{array}$ \\
\hline
\end{tabular}


Based on the collocates appearing immediately after the self-mention 'I' (Table 5), it is found that Syahredzan has more variety in the use of the personal pronoun than his counterpart. One interesting finding is the different use of verbs to describe mental processes with the self-mention 'I', i.e. Syahredzan uses more emotive verbs like I feel/love and therefore appears to be more personal compared to John. Syahredzan also uses the reflexive pronoun 'myself' after 'I' (I myself have been guilty of this; I will tell myself that we can rise above the prejudice and suspicion if only we focus on our similarities instead of our differences), which in turn increases/intensifies the personalization of his writing. It is also found that Syahredzan uses the cognitive verb 'know' (see Figure 2) whereas John uses 'I' with cognitive verbs like 'think' when referring to personal opinions (Figure 3). This implies that Syahredzan is more assertive in his claims while John remains cautious.

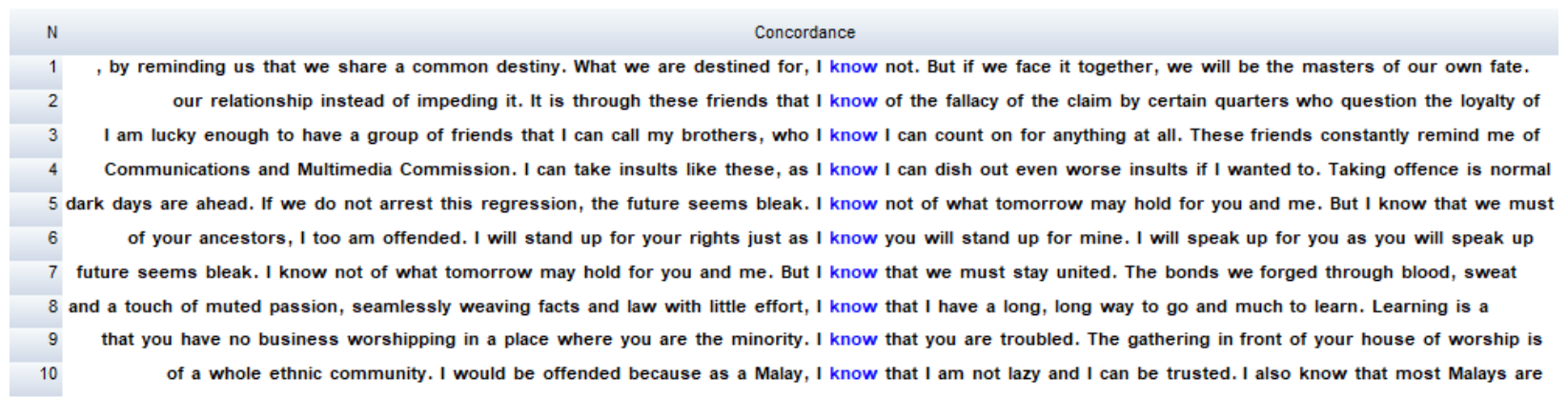

Figure 2: 'I know' in Syahredzan

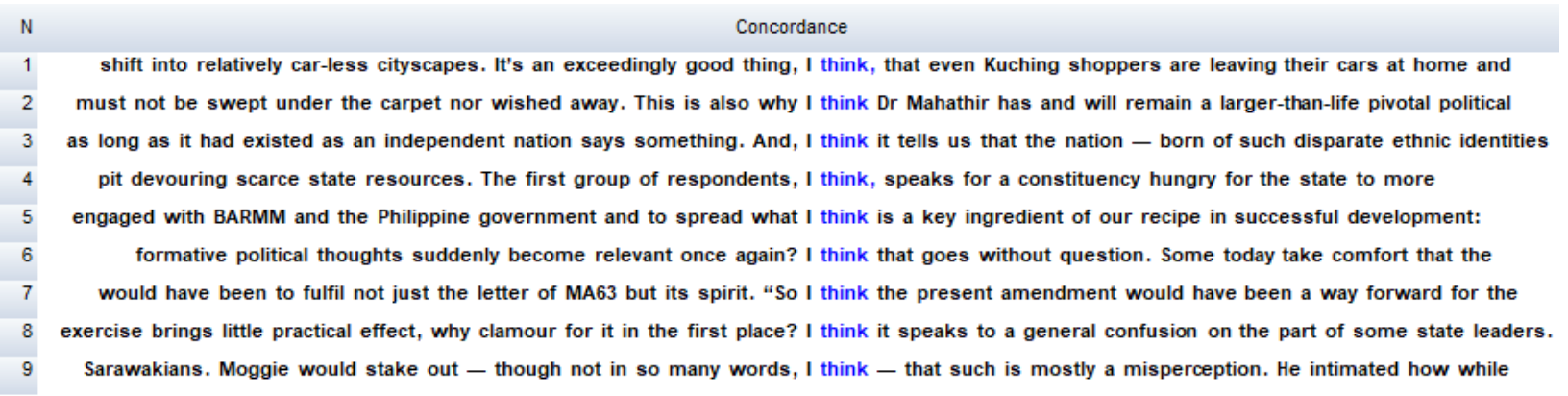

Figure 3: 'I think' in John

Similar use of self-mention 'I's in both columnists' writings are highlighted in bold above, including existential use of the self-mention with patterns like I am, I was and I have. However, further investigation of concordance lines reveal that they are used differently between the writers. 
Although 3 out of 9 of John's examples of 'I am' are actually quotes from other people, he expresses his conviction and confidence when he uses I am + so sold/even seriously contemplating on talks about UTC. He also shows his confidence in relation to his belief of the society as a form of solidarity in

5) Therefore, if we believe that our society has progressed and grown in sophistication over the years (which I am confident means most of us), we must necessarily place greater trust in our own capacity to keep our own society progressing, going forward.

Another use of the self-mention phrase is used when John reflects on the past:

6) I am reminded of almost similar conditions now prevailing in our country obtaining a generation ago when the so-called "people power" revolution of 1986 overthrew then Philippine president Ferdinand Marcos.

Other forms of 'I am' occur in expressions that suggest hedging like "...as far as I am concerned”, and "I am sure that...". Meanwhile, Syahredzan makes more use of the 'I am' phrase as shown in Figure 4 below. This variation of use, especially those expressing attitudinal stance (e.g. I am lucky enough; I am clueless about; I am honoured/still passionate about; I am not lazy; I am serious, no kidding and others) suggests that his writing is more personalised. 


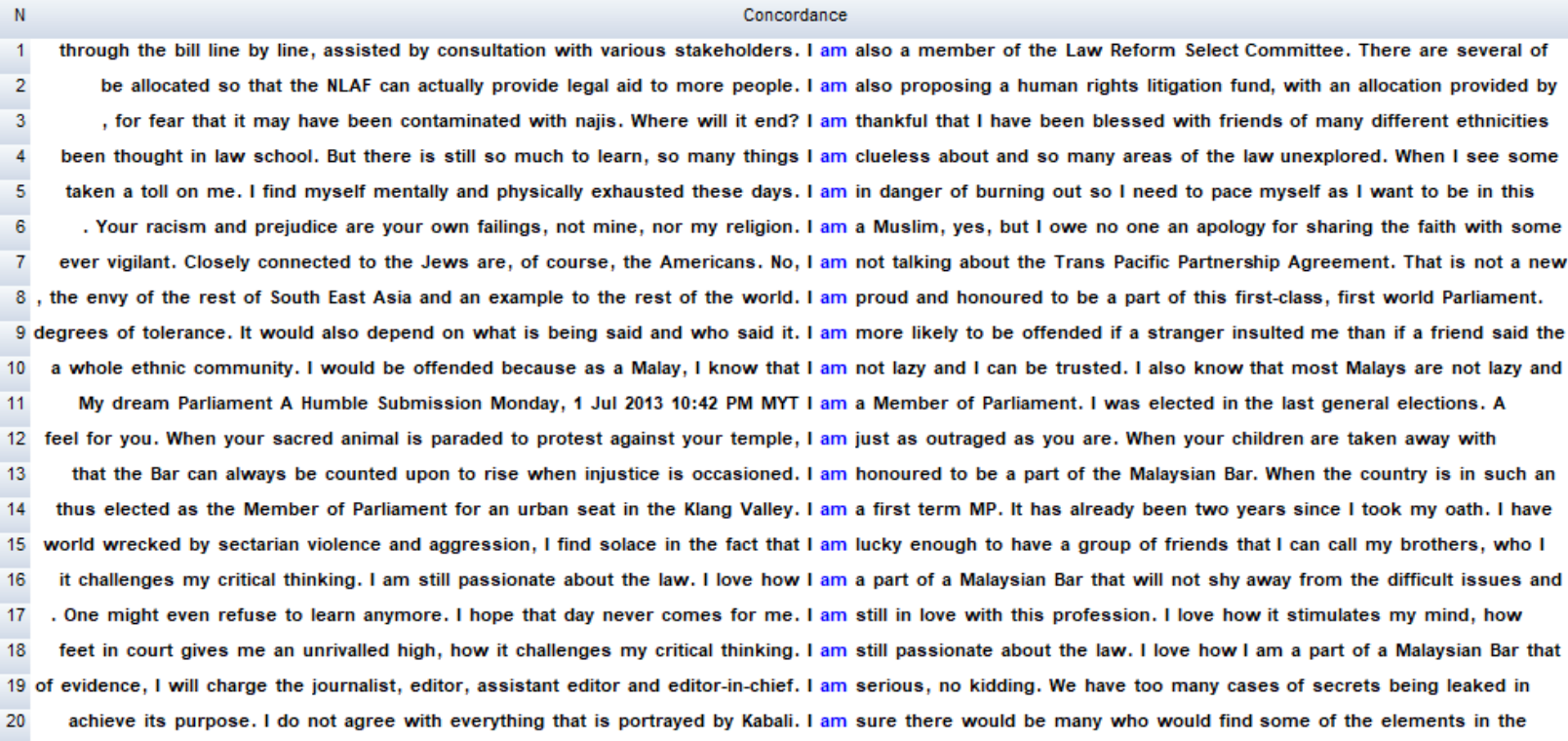

Figure 4: 'I am' in Syahredzan

As regards the use of existential phrase 'I was', it was found that Syahredzan makes more mention of his emotional state of being, which was not found in John. This adds more to Syahredzan more personalised views than his counterpart (examples 7 - 12).

7) I was angry with those who had committed such a heinous act on innocent civilians. And I feared for the backlash on Muslims living in Britain at that time.

8) I was more reckless, brash and less matured, so I had to learn the hard way through these mistakes.

9) As I watched the scene of mayhem from my television screen in Cardiff that day, emotions of sadness, anger and fear swept over me. I was sad for the country I lived in.

10) I recently decided to trim my Facebook friends list. I was foolish enough before to approve almost all friend requests that came my way without any sort of filtering process.

11) Twitter was still new to Malaysians at that time and I was even lucky enough to participate in what was probably the first Malaysian 'tweetup' (tweetup = Twitter meet up), way before tweetups were 'uncool' as they are now.

12) I was also worried about the overnight stay as there was nothing to stop troublemakers from disrupting the rally in the dead of night. 
In terms of the final shared use of self-mention 'I' among both columnists, Syahredzan (again) displays a more emotive stance with the use of passive form 'I have been' (e.g. I have (also) been lucky/blessed/always been passionate). Interestingly, he also makes mention of his actions in the past, and to which he reflects on in his writings (examples $13-15$ ).

13) When I see some senior lawyers on their feet, articulately submitting to the court with eloquence and a touch of muted passion, seamlessly weaving facts and law with little effort, I know that I have a long, long way to go and much to learn.

14) I have learned much over the past seven years.

15) Yes, I have made many, many mistakes, both outside court and in court.

Other instances reflect Syahredzan's personal relationship with his close friends (e.g. I have known this group/them/these friends) and further add to his personalised writing style. John on the other hand, only used the 'I have' phrase in the following two instances. Interestingly, it can be seen that he constructs this phrase as an embedded clause and in turn, adds to the description of hedging in his writing.

16) The early years of Merdeka right up to Malaysia Day in 1963 are, of course, years I have little to no personal memory of, except for that etched in my young mind of being caught literally in the crossfire in the Limbang revolt of 1962 as our family hid in the concrete bathroom to dodge live bullets fired into our wooden, stilted government bungalow.

17) Because, since giving up on a regular 9 to 5 job, what I have discovered to be one of the more liberating perks is not to be held slave to the electronically-inspired call of duty.

\section{Conclusion and Recommendations}

To reflect on the digital news reports by Reuters $(2018,2019)$, it is inevitable that from today onwards, more news will be read online and this includes commentary writing. Although we have acknowledged the discrepancy of online versions and their broadsheets, we argue that the wider readership of columns online rather than its broadsheet counterpart show that columnists have more influence if any, to be more persuasive in the digital realm. As Hall (2008) points out, "community journalisms [such as columnists], which before the web were regarded by the larger 
news organisations as marginal and unprofitable, $[\ldots]$ have helped to show journalism how to make news a fully interactive process" (p. 211) and that the "personality of particular writers, expressed in style and content, became a way of attracting readers to a publication” (McNair, 2008, p. 109).

This paper for the most part, has attempted to show this by investigating Malaysian columnist English writing that focused on the examination of metadiscoursal features as rhetorical strategies, via corpus linguistics. Two columnists from The Star Online and News Straits Times were analysed to discern stylistic differences in their writings. Findings revealed that while differences show topic-related words are nothing interesting to the writers, shared functional words on the other hand reveal some distinctions. In brief, Syahredzan was depicted as more personal in his writings compared to John Teo, mainly given his more frequent and various use of interactive and interactional metadiscourse features. The presence of metadiscourse in the corpus of Malaysian opinion columns was found to be consistent with the findings of Dafouz-Milne (2008) and Noorian and Biria (2014), in that the construction of persuasion in the newspaper opinion columns can be achieved through the use of metadiscoursal features.

The comparisons between the two experienced columnists have revealed distinctive styles and their stylistic projection of newsworthiness. Bednarek (2015) notes, newsworthiness is "treated as a quality of news media talk and text, and news values are conceptualised as the 'newsworthy' aspects of actors and events as constructed through linguistic resources (p28)." In particular, the findings described how the columnists would attract readers to their articles, specifically when Hyland's (2005) metadiscoursal features were employed. As argued in the paper, columns are generally another way of reporting news, and how they are written would therefore, function to connect or engage with readers. The stylistic differences between the two columnists in this study therefore contribute to the description of journalistic discourse. As McNair (2008) puts it, the columnist stresses the 'I', as opposed to the detached objectivity of the reporter/correspondent. The use of the personal pronoun 'I' has been found to characterise online columns by producing a sense of solidarity with readers and in turn, contributing to reader-writer interaction/visibility. As noted by Coward (2013), "columns not only use personal pronouns and even personal anecdotes, they require them. The writing is all about communicating a distinctive personality both in content and style, the more distinctive, the better" (p. 35). 
Despite the differences in style choices, both online columnists commonly employ interactional metadiscourse features as a means to organize the discourse; to help them create meanings and negotiate their ideas with their readers. It can be suggested that the choices that columnists make in their writing may determine the effect on their readers. While Syahredzan may elicit a more personalized and assertive stance (e.g. I feel/lovelknow), John uses the 'I' with the cognitive verb 'think' and modal verbs like 'would' and 'can', indicating scepticisms or reservations. Unique to news reporting, columnists have a significant role in reporting news, as McNair (2008) highlights, they have the added flair to present and analyse the news via their personal lens. Pape and Featherstone (2006) assert that "personal columns and the views expressed in them are part of a newspaper's personality. Certainly, they are one of the very few places where a dialogue is established between reader and writer and as such, they have an important role in establishing the personality and soul of a paper" (p. 89). This characterises the online column discourse, in which the readers have a special relationship with the columnists. Readers look to specific columnists for a distinct style, point of view and informed opinion. In other words, it is the columnist, not the newspaper that attracts the readers.

Thus, online columns may reflect attitudes and viewpoints of a society and in turn, influence our (readers') reaction to various issues, since they are written by independent experts from various vantage points in the society. This is notwithstanding that more recent views on columnists have declined - mostly due to the digital change/development of things that creates an increase of subjectivity, lesser objectivity in presenting the news. McNair notes that "[ $[\mathrm{t}] \mathrm{he}$ rise of the internet has sharpened debates about the mobilisation and measurement of trust and authority in journalistic discourse" (2008, p. 113) and that fake news, for example may be a result of declining rhetoric in journalism. In light of this, digitizing has also provided a platform for readers to even respond to opinion pieces (consider the reader's feedback at the bottom of the online article -sometimes together with emojis/likert scale for feedback), resulting in what we call as an opinion within an opinion. This in turn, creates a wealth of possible future research avenues. Additionally, this study reveals ways to use corpus techniques for analysing news media/content (i.e. news, articles, and column pieces), which may benefit those who wish to study media and journalism. 


\section{Acknowledgements}

We would like to thank the anonymous reviewers for their constructive comments/feedback that have helped shape the final manuscript.

\section{References}

Baker, P., Gabrielatos, C. \& McEnery, A. (2013). Discourse Analysis and Media Attitudes: The representation of Islam in the British Press. Cambridge: Cambridge University Press.

Baker, P., Gabrielatos, C., Khosravinik, M., Krzyzanowski, M., McEnery, T., \& Wodak, R. (2008). A useful methodological synergy? Combining critical discourse analysis and corpus linguistics to examine discourses of refugees and asylum seekers in the UK press. Discourse and Society, 19(3), 273-306.

Bednarek, M. \& Caple, H. (2014). Why do news values matter? Towards a new methodological framework for analysing news discourse in Critical Discourse Analysis and beyond. Discourse \& Society, 25(2), 135-158.

Bernstein, A., \& Galily, Y. (2008). Games and sets: Women, media and sport in Israel. Nashim A Journal of Jewish Women's Studies and Gender Issues, 15(1), 175-196.

Biber, D., Johansson, S., Leech, G., Conrad, S. \& Finegan, E. (1999). Longman Grammar of Spoken and Written English. Harlow, England: Pearson Education.

Bird, S. E.. (2011). Seeking the audience for news: Response, news talk, and everyday practices. In: V. Nightingale (ed.). The Handbook of Media Audiences. Oxford: Blackwell Publishing Ltd., 489-508.

Coward, R. (2013). Speaking personally: The rise of subjective and confessional journalism. Hampshire: Palgrave Macmillan.

Culpeper, J. (2002). Computers, language and characterisation: An Analysis of six characters in Romeo and Juliet. In: U. MelanderMarttala, C. Ostman and Merja Kyto (eds.), Conversation in Life and in Literature: Papers from the ASLA Symposium, Association Suedoise de Linguistique Appliquee (ASLA), 15. Universitetstryckeriet: Uppsala, 11-30.

Dafouz-Milne, E. (2008). The pragmatic role of textual and interpersonal metadiscourse markers in the construction and attainment of persuasion: A cross-linguistic study of newspaper discourse. Journal of Pragmatics, $40 \quad$ 95-113. https://doi.org/10.1016/j.pragma.2007.10.003 
Djerf-Pierre, M., \& Shehata, A. (2017). Still an agenda setter: Traditional news media and public opinion during the transition from low to high choice media environments. Journal of Communication, 67 (5), 733-757. https://doi.org/10.1111/jcom.12327

Fairclough, N. (1995). Media Discourse. London: Edward Arnold.

Fu, X., \& Hyland, K. (2014). Interaction in two journalistic genres: A study of interactional metadiscourse. English Text Construction, 7(1), 122-144.

Khabbazi-Oskouei, L. (2013). Propositional or non-propositional, that is the question: A new approach to analyzing 'interpersonal metadiscourse' in editorials. Journal of Pragmatics, 47(1), 93-107.

Hall, J. (2008). Online editions: newspapers and the 'new' news. In Franklin, B. (Ed.), Pulling Newspapers Apart: Analysing Print Journalism (pp. 215-223). London: Routledge.

Hunston, S. (2002). Methods in corpus linguistics: Beyond the concordance line. In S. Hunston (Ed.), Corpora in applied linguistics (pp. 67-95). Cambridge: Cambridge University Press.

Hyland, K. (2005). Stance and engagement: A model of interaction in academic discourse. Discourse Studies, 7(2), 173-191.

Hyland, K. (2004). Disciplinary interactions: Metadiscourse in L2 postgraduate writing. Journal of Second Language Writing, 13, 133-151.

Jaworska, S., \& Krishnamurthy, R. (2012). On the F word: A corpus-based analysis of the media representation of feminism in British and German press discourse, 1990-2009. Discourse \& Society, 23(4), 401-431.

Jaworska, S. (2016) Using a corpus assisted discourse studies (CADS) approach to investigate constructions of identities in media reporting surrounding mega sport events: The case of the London Olympics 2012. In: Lamond, I. R. and Platt, L. (Eds.) Critical Events Studies: Approaches to Research. Leisure Studies in a Global Era. Palgrave Macmillan, Basingstoke, pp. 149-174. doi: https://doi.org/10.1057/9781137523860_8. Available at http://centaur.reading.ac.uk/43261/

Mahlberg, M. (2013). Corpus Stylistics and Dickens's Fiction. London: Routledge.

McEnery, T. \& Hardie, A. (2012). Corpus Linguistics: Method, theory and practice. Cambridge: Cambridge University Press.

McNair, B. (2008). I, Columnist. In Franklin, B. (Ed.), Pulling Newspapers Apart: Analysing Print Journalism (pp. 106-114). London: Routledge. 
Mengyu, H.E., \& Hajar, A.R. (2019). Comparing Engagement Markers in Economics Research Articles and Opinion Pieces: A Corpus-based Study. GEMA Online® Journal of Language Studies, 19 (2), 1-14. http://doi.org/10.17576/gema-2019-1902-01

Meikle, G. (2008). Naming and shaming: News satire and symbolic power. The Electronic Journal of Communication, $18(2, \quad 3 \quad \& \quad 4) . \quad$ Available at http://www.cios.org/www/ejc/EJCPUBLIC/018/2/01847.html

Noorian, M, \& Biria, R. (2014). Interpersonal Metadiscourse in Persuasive Journalism: A Study of Texts by American and Iranian EFL Columnists. Journal of Modern Linguistics, 20, 6479.

O'Halloran, K. (2010). How to use corpus linguistics in the study of media discourse. In O'Keeffe, Anne and McCarthy, Michael eds. The Routledge Handbook of Corpus Linguistics (pp. 563577). Abingdon: Routledge.

O’Keeffe, A. (2006). Invesitgating Media Discourse. London: Routledge.

O'Keeffe, A. (2011). Media and Discourse Analysis. In: Gee, J. \& Handford M. (eds), The Routledge Handbook of Discourse Analysis (pp. 441-454). London: Routledge.

Partington, A. (2006). The linguistics of laughter: A corpus-assisted study of laughter-talk. London: Routledge.

Partington, A., Duguid, A. \& Taylor, C. (2013). Patterns and Meanings in Discourse. Theory and Practice in Corpus-Assisted Discourse Studies. Amsterdam: John Benjamins.

Pape, S. \& Featherstone, S. (2006). Feature Writing: A Practical Introduction. London: SAGE Publications.

Reese, S. D., Rutigliano, L., Hyun, K., \& Jeong, J. (2007). Mapping the blogosphere: Professional and citizen-based media in the global news arena. Journalism, 8(3), 235-261.

Reuters Institute Digital News Report. (2018). Oxford: Reuters Institute for the Study of Journalism.

Reuters Institute Digital News Report. (2019). Oxford: Reuters Institute for the Study of Journalism.

Rogers, T. (2019, July 15). Differences between Broadsheet and Tabloid Newspapers. Retrieved from https://www.thoughtco.com/broadsheet-and-tabloid-newspapers-2074248

Scott, M. (2012). WordSmith Tools version 6, Liverpool: Lexical Analysis Software. 
Semino, E. and Short, M. (2004). Corpus Stylistics: Speech, Writing and Thought. Presentation in a Corpus of English Writing. London: Routledge.

Taylor, C. (2014) Investigating the representation of migrants in the UK and Italian press: A crosslinguistic corpus-assisted discourse analysis. International Journal of Corpus Linguistics, 19 (3), 368-400.

van Djik, T. (1993). Principles of critical discourse analysis. Discourse and Society, 4 (2), 249283.

Vaughan, E. \& O’Keeffe, A. (2015). Corpus Analysis. In K. Tracy, C. Ilie \& T. Sandel (Eds.). The International Encyclopedia of Language and Social Interaction (pp. 252-268). Denver: John Wiley \& Sons.

Wodak, R. (2001). What CDA Is about-A Summary of Its History, Important Concepts and Its Developments. In W. R., \& M. Meyer (Eds.), Methods of Critical Discourse Analysis (pp. 1-13. London: Sage. 


\section{Appendix}

Table A1: Shared key words in both corpora

\begin{tabular}{|c|c|c|c|c|c|c|c|}
\hline $\mathbf{N}$ & Key word & $\begin{array}{c}\text { freq. in } \\
\text { Syahredza } \\
\mathbf{n} \\
\text { Johan_files }\end{array}$ & $\%$ & Texts & $\begin{array}{c}\text { freq. in } \\
\text { John } \\
\text { Teo_file } \\
\text { s } \\
\end{array}$ & RC. $\%$ & $\begin{array}{c}\text { Keynes } \\
\text { s }\end{array}$ \\
\hline 1 & the & 7036 & 7.76 & 132 & 11988 & 6.15 & 249.29 \\
\hline 2 & of & 3036 & 3.35 & 132 & 5661 & 2.91 & 40.06 \\
\hline 3 & is & 1689 & 1.86 & 132 & 2430 & 1.25 & 157.47 \\
\hline 4 & not & 983 & 1.08 & 130 & 1135 & 0.58 & 198.35 \\
\hline 5 & by & 765 & 0.84 & 130 & 1061 & 0.54 & 82.92 \\
\hline 6 & have & 601 & 0.66 & 126 & 897 & 0.46 & 46.53 \\
\hline 7 & are & 771 & 0.85 & 126 & 895 & 0.46 & 152.99 \\
\hline 8 & this & 578 & 0.64 & 130 & 767 & 0.39 & 74.37 \\
\hline 9 & was & 431 & 0.48 & 101 & 670 & 0.34 & 26.75 \\
\hline 10 & or & 739 & 0.81 & 123 & 606 & 0.31 & 308.20 \\
\hline 11 & we & 631 & 0.70 & 109 & 564 & 0.29 & 226.40 \\
\hline 12 & there & 347 & 0.38 & 119 & 414 & 0.21 & 63.40 \\
\hline 13 & they & 359 & 0.40 & 105 & 394 & 0.20 & 82.49 \\
\hline 14 & who & 283 & 0.31 & 105 & 319 & 0.16 & 60.62 \\
\hline 15 & must & 348 & 0.38 & 96 & 312 & 0.16 & 123.91 \\
\hline 16 & also & 306 & 0.34 & 113 & 300 & 0.15 & 91.27 \\
\hline 17 & should & 253 & 0.28 & 95 & 226 & 0.12 & 90.63 \\
\hline 18 & these & 267 & 0.29 & 100 & 206 & 0.11 & 122.18 \\
\hline 19 & would & 282 & 0.31 & 104 & 204 & 0.10 & 141.75 \\
\hline 20 & people & 261 & 0.29 & 84 & 198 & 0.10 & 122.49 \\
\hline 21 & under & 157 & 0.17 & 68 & 194 & 0.10 & 25.72 \\
\hline 22 & do & 240 & 0.26 & 93 & 191 & 0.10 & 104.67 \\
\hline 23 & were & 167 & 0.18 & 68 & 185 & 0.09 & 37.41 \\
\hline 24 & I & 162 & 0.18 & 31 & 110 & 0.06 & 88.62 \\
\hline 25 & right & 173 & 0.19 & 55 & 107 & 0.05 & 106.19 \\
\hline 26 & without & 111 & 0.12 & 61 & 88 & 0.05 & 48.66 \\
\hline 27 & why & 89 & 0.10 & 55 & 84 & 0.04 & 28.65 \\
\hline 28 & cannot & 94 & 0.10 & 59 & 83 & 0.04 & 34.35 \\
\hline 29 & rights & 156 & 0.17 & 41 & 81 & 0.04 & 115.37 \\
\hline 30 & media & 140 & 0.15 & 32 & 75 & 0.04 & 100.38 \\
\hline 31 & law & 304 & 0.34 & 81 & 73 & 0.04 & 382.93 \\
\hline 32 & however & 80 & 0.09 & 56 & 73 & 0.04 & 27.50 \\
\hline 33 & order & 100 & 0.11 & 54 & 71 & 0.04 & 51.52 \\
\hline 34 & does & 115 & 0.13 & 65 & 70 & 0.04 & 71.88 \\
\hline 35 & assembly & 91 & 0.10 & 20 & 65 & 0.03 & 46.50 \\
\hline 36 & social & 94 & 0.10 & 26 & 61 & 0.03 & 54.44 \\
\hline 37 & act & 335 & 0.37 & 66 & 56 & 0.03 & 490.52 \\
\hline 38 & parliament & 151 & 0.17 & 51 & 51 & 0.03 & 157.11 \\
\hline
\end{tabular}




\begin{tabular}{|c|c|c|c|c|c|c|c|}
\hline 39 & want & 67 & 0.07 & 38 & 50 & 0.03 & 32.17 \\
\hline 40 & know & 59 & 0.07 & 30 & 45 & 0.02 & 27.43 \\
\hline 41 & say & 69 & 0.08 & 42 & 44 & 0.02 & 40.82 \\
\hline 42 & days & 66 & 0.07 & 36 & 41 & 0.02 & 40.28 \\
\hline 43 & known & 62 & 0.07 & 49 & 41 & 0.02 & 35.06 \\
\hline 44 & used & 63 & 0.07 & 40 & 40 & 0.02 & 37.46 \\
\hline 45 & constitutional & 66 & 0.07 & 32 & 39 & 0.02 & 42.65 \\
\hline 46 & citizens & 60 & 0.07 & 23 & 38 & 0.02 & 35.78 \\
\hline 47 & action & 51 & 0.06 & 25 & 38 & 0.02 & 24.54 \\
\hline 48 & religious & 50 & 0.06 & 26 & 37 & 0.02 & 24.30 \\
\hline 49 & certain & 81 & 0.09 & 44 & 36 & 0.02 & 68.87 \\
\hline 50 & society & 74 & 0.08 & 44 & 36 & 0.02 & 58.15 \\
\hline 51 & human & 78 & 0.09 & 26 & 34 & 0.02 & 67.39 \\
\hline 52 & court & 222 & 0.24 & 55 & 33 & 0.02 & 338.15 \\
\hline 53 & comes & 49 & 0.05 & 35 & 30 & 0.02 & 30.41 \\
\hline 54 & rakyat & 55 & 0.06 & 27 & 28 & 0.01 & 41.43 \\
\hline 55 & constitution & 184 & 0.20 & 51 & 27 & 0.01 & 281.39 \\
\hline 56 & young & 61 & 0.07 & 17 & 26 & 0.01 & 53.66 \\
\hline 57 & you & 238 & 0.26 & 40 & 25 & 0.01 & 400.07 \\
\hline 58 & bill & 101 & 0.11 & 20 & 25 & 0.01 & 125.24 \\
\hline 59 & found & 44 & 0.05 & 31 & 25 & 0.01 & 29.67 \\
\hline 60 & legislative & 40 & 0.04 & 25 & 25 & 0.01 & 24.23 \\
\hline 61 & islamic & 45 & 0.05 & 16 & 24 & 0.01 & 32.39 \\
\hline 62 & muslims & 87 & 0.10 & 17 & 23 & 0.01 & 104.33 \\
\hline 63 & claim & 45 & 0.05 & 22 & 23 & 0.01 & 33.77 \\
\hline 64 & freedom & 161 & 0.18 & 41 & 22 & 0.01 & 251.74 \\
\hline 65 & security & 98 & 0.11 & 28 & 21 & 0.01 & 129.94 \\
\hline 66 & legal & 86 & 0.09 & 32 & 20 & 0.01 & 109.88 \\
\hline
\end{tabular}

